\title{
Ethnologies
}

\section{Canada Research Chair in Intangible Cultural Heritage}

\section{Richard MacKinnon}

Volume 29, numéro 1-2, 2007

Retour à l'ethnographie

Back to Ethnography

URI : https://id.erudit.org/iderudit/018759ar

DOI : https://doi.org/10.7202/018759ar

Aller au sommaire du numéro

Éditeur(s)

Association Canadienne d'Ethnologie et de Folklore

ISSN

1481-5974 (imprimé)

1708-0401 (numérique)

Découvrir la revue

Citer cet article

MacKinnon, R. (2007). Canada Research Chair in Intangible Cultural Heritage. Ethnologies, 29(1-2), 343-355. https://doi.org/10.7202/018759ar d'utilisation que vous pouvez consulter en ligne.

https://apropos.erudit.org/fr/usagers/politique-dutilisation/ 


\title{
Canada Research Chair in Intangible Cultural Heritage
}

\author{
Richard MacKinnon \\ Cape Breton University \\ Richard_Mackinnon@uccb.ca
}

\section{Oral Traditions and Expressions}

One of the goals of establishing this chair is for Cape Breton University to continue to show leadership in the study of folklore and endangered traditional cultural expressions. The Chair will sponsor CDROM, video and audio collection/research projects as well as scholarly books and articles to preserve and interpret threatened or vulnerable aspects of culture. There is a worldwide need for research, publication and policy development in this emerging field (Hufford, 1994; Loomis, 1983). First, there is no clear and comprehensive inventory of intangible cultural heritage of this region. The Research Chair will systematically identify and continue to update an inventory of the region's threatened intangible cultural heritage (ICH). The academic and popular publications that will result from this study will offer examples and suggestions for the protection and preservation of ICH. This, in turn, can serve as a model for the development of inventories in other regions and countries. The Chair recognizes that the protection of folklore resources must also proceed with local recognition that the tradition is valued for it to be maintained and continued. What conditions or factors help to condone the perpetuation and maintaining of local cultural traditions? The chair will identify a mechanism to solicit recommendations from individual tradition bearers on the preservation of traditions; it has been shown that general public hearings are not particularly effective forums for gathering this kind of information (Hufford 1986: 111). 
Cape Breton Island is an ideal location to take international leadership with this research. The Island has many distinctive cultural groups including Scottish, Irish, English Loyalists, Acadian French, Ukrainian, Italian, Polish, Czechoslovakian, African-American, Chinese, etc. Furthermore, it is home to five Aboriginal First Nation communities. The Mi'kmaq people are the original inhabitants of the island and are now planning to develop their own museums and Arts and Culture Centres with a view toward preserving aspects of their distinctive cultural traditions. In addition, the island is now experiencing severe structural change from a resource to a postindustrial, knowledgebased economy. The island has become an international leader in the field of social economy through its Community Economic Development research and interventions, while at the same time, the tourism, culture, arts, and heritage sectors are experiencing vibrant growth. For these reasons, the island can be viewed as a laboratory for studying innovative ways to protect, preserve, and educate people about intangible cultural heritage. The practical lessons learned will be applicable to other regions and multicultural countries who are experiencing similar structural transformations in their economies. The research conducted by the Chair will be valuable to UNESCO and their participating member states in their attempts to create a multilateral instrument for the conservation of ICH.

\section{Culture Related to Work}

While extensive work has been completed on the history of coal mining (Campbell 1997; Frank 1999; Hornsby 1992; MacGillivray 1980; McKay 1988; Muise and McIntosh 1996; Ryan 1992), the fishery (Balcom 1984; Innis 1978), and the steel industry (Candow 2001; Earle 2001; Frank and MacGillivray 1987; Heron 1988; MacEwan 1976), fewer studies have focused on the distinctive traditions and expressive culture of fishers, coal miners, steelworkers and their families (Davey and MacKinnon 1996; Frank 1985). What traditions and local knowledge are being lost with the closing down of these primary industries? Will the cultural knowledge of mining disappear? The Nominee will conduct research with fishers, miners, steelworkers and their families and with members of the diverse cultural groups that have shaped the island. Recording of fishing, local mining and steel making terms is one topic area that needs to be collected, studied and interpreted before older workers are no longer available to pass this 
work terminology along. (Korson 1965, 1979; Preston 1973). The nominee will conduct this research in a team approach with a postdoctoral researcher, graduate students, and undergraduate students, all who have training in Folklore fieldwork. There is a history of this team approach in both anthropology and folklore and it has proven to be effective. As Mary Hufford notes: "A team of researchers with varied ethnographic backgrounds and training can produce a holistic picture, while checking some of the biases that individual researchers inevitably bring to their work"(Hufford 1986, p.128). This research has global application. As older work patterns disappear with changes in the economy, when mines and steel mills close, or when overuse of a resource destroys an economic base, traditional knowledge disappears. This can happen quickly. Other areas such as East Germany, the midlands of England, Appalachia and Pennsylvania in the United States, British Columbia, Canada and Wallonia, Belgium are only some areas in the midst of post coal and steel transformation. The detailed work knowledge required for underground, submarine coal mining, can disappear within one generation when older workers do not pass on their knowledge and skills to younger workers. This loss of traditional knowledge is occurring at a fast pace throughout much of the western world; there are few concerted efforts to research and understand this process. Capturing the traditional knowledge of one community that is experiencing structural transformation can have enormous impact on our global understanding of postindustrialism (Knapp 1998).

The Nominee has already begun some of this needed work. Along with CBU colleague Dr. Bill Davey, he has published a number of scholarly articles on the oral tradition of nicknaming prevalent in coal mining communities based on oral interviews with former miners and their families (MacKinnon 2000; Davey and MacKinnon 1996; Davey and MacKinnon 1996). Further work under the Canada Research Chair will be conducted to complete a book on the endangered oral traditions of mining communities. This Cape Breton material can then be compared to other mining regions such as British Columbia, Pennsylvania and East Germany (Bowen 1982, 1986, 1999; Colls 1977; Fowke 1969; Green 1972; Lloyd 1952, 1954; Muise 1996; Newsome, 1989).

As well as studying various threatened traditions surrounding the world of work, there is a need to record, through oral history, the life stories of members of fast disappearing sub-groups such as the Jewish 
community on the Island. There is a tradition of members of the Jewish community being business leaders and philanthropists in this region and there is a need to record this oral history before it is no longer available. This project will allow university researchers to work with local community groups, as well as with other expert scholars who have studied this issue in other regions of Canada and the United States.

The Nominee will partner with local museums and cultural/heritage organizations that are interested in preserving and researching aspects of the cultural traditions of some of the island's people. For example, the Nova Scotia Highland Village, a member of the Nova Scotia museum system, is devoted to studying and educating the public about Nova Scotia's Gaelic Culture. The Nominee will partner with this living history museum to develop projects that aid in better understanding and preservation of threatened Gaelic folklore and tradition and to better understand the Scottish diaspora throughout the world. For example, more research is required on the connection between Cape Breton Island and Waipu, New Zealand, where Cape Breton Scottish people migrated to in the mid-nineteenth century. What traditional culture continued in this new setting? When and why, for example, did the Gaelic language begin to disappear? What symbols do Waipu settlers use to carry on their Scottish identity? What does this tell us about the dynamics of tradition, migration, cultural stability and change?

\section{Performing Arts: Cape Breton Music}

The International Council for Traditional Music (ICTM) is a nongovernmental organization in formal consultative relations with UNESCO. The aims of the ICTM are to further the study, practice, documentation, preservation, and dissemination of traditional music, including folk, popular, classical and urban music, and dance of all countries. Many issues regarding the preservation of music and dance, include threatened traditions caused by such things as technology replacing traditional forms of music making, and consumption replacing participation; local music practice sometimes being treated with social prejudice; and the difficulty incorporating local music traditions into formal education, to name a few. This international focus on preserving traditional music has direct implication for the study of traditional Cape Breton music. 
Cape Breton Island is one of many international communities with distinctive music and dance traditions. The Canada Research Chair in Intangible Culture will make the study of Cape Breton Musical tradition one of its priorities. Between 1775 and 1850, more than twenty-five thousand Gaelic-speaking Scots from every region of the Highlands and Islands established communities throughout Cape Breton and Eastern Nova Scotia. They brought with them their Gaelic language and many of their distinctive oral and musical traditions. Through their interaction with the other established people on the island, a distinctive fiddle and piano style emerged that is connected to its own distinctive step dance and square dance tradition. These island traditions are now receiving international attention, and Cape Breton Island performers travel the world bringing this unique form of creativity to others far beyond the island. An International Celtic music festival, "Celtic Colours" attracts musicians and visitors from all over the world each October to visit the island and to explore these distinctive traditions. Each year, over 300 artists from all over the Celtic world, including Scotland, Ireland, the United States, Brittany, and Canada perform at over thirty venues around the island. In 2003 people came to Celtic Colours from every province and territory in Canada, forty-five U.S. States and eighteen other countries. Much more collection, study and analysis of the various island musical traditions are necessary to outline the various ways in which this unique tradition has developed and emerged over time. To what degree are these traditions conservative? How are they innovative? What are the conditions that promote the continued development of these traditions? How are these traditions changing at the present with the influences from festivals such as Celtic Colours? These are only a few of the research questions that need to be explored.

Before some of these complex issues can be explored, a comprehensive history of music on the island needs to be completed that discusses all styles and forms found in this distinctive region. There are a few popular publications and some theses and dissertations that primarily focus on the distinctive Cape Breton fiddle tradition, but few other areas have been researched (Doherty 1996; Dunlay 1996; MacGillivray 1981, 1988; MacInnes 1997; I. MacKinnon 1989).

Equally important issues to examine are the changes in how music has been passed on in families and communities. Historically this was done in families, ceilidh houses and people's homes in a traditional way 
through informal learning. To what degree is this still the case? Are there more formal music lessons in contemporary Cape Breton or are contexts created today that allow for the traditional forms of learning to continue? This project is not limited to Celtic or Mi'kmaq music but would include all genres of music from traditional to country and western, blues, jazz, bluegrass big band and rock and roll. The preliminary work on this will form the basis for a CURA research grant or a MultiCollaborative Research project/s that will bring together international folklorists and ethnomusicologists as well as local groups and organizations interested in the study of traditional music and music history. Scholars to be approached include people who have already shown interest in Cape Breton music such as Burt Feintuch, University of New Hampshire, Kate Dunlay, Halifax, Peter Narváez, Memorial University of Newfoundland, Beverly Diamond, Memorial University of Newfoundland, Liz Doherty, University of Cork, Ireland, Ronald Labelle, Université de Moncton, Barbara Leblanc, Université Ste-Anne, and Gordon Smith, Queen's University. Local and international organizations include: Celtic Colours International Festival organizers Joella Foulds and Max MacDonald, Celtic Music Interpretative Centre, Judique; The Nova Scotia Highland Village, Iona, Cape Breton, The Highland Folk Museum, Kincussie, Scotland; Smithsonian; American Folklife Centre, Library of Congress, Washington; Mi'kmaq Association for Cultural Studies, Peter Christmas and Debra Ginnish, Les Trois Pignons, Cheticamp, New Waterford Historical Society, and Centre for Cape Breton Heritage and Science, Sydney.

This research will help lead to digitization projects to preserve and protect some historical collections of music that currently exist but are threatened because of the age and conditions of the original taped audio and video recordings. Some of the research generated by the Chair will be distributed in the form of video and multimedia projects that aim to aid the general public and the secondary school system. The Nominee has demonstrated expertise in the multimedia field, collaborating with faculty from inside and outside CBU and the Nova Scotia business community on a number of major multimedia projects.

The study and digital preservation of traditional Cape Breton music aims at presenting popular or learned musical traditions from this cultural region as a witness to current modes of expression that are highly representative of the Cape Breton heritage, civilization, musical system 
and artistic creativity. The nominee will submit research outcomes to UNESCO Collection of Traditional Music.

\section{Vernacular Architecture and Material Culture:Traditional Craftsmanship}

A region or neighborhood's vernacular architecture and material culture are expressions of a community's personality. A region's needs, tastes and cultural expressions are shown in the way people design, build and use their homes and buildings. Features that make a neighborhood or community a distinct region - the public spaces, the types of buildings, the decorative details and the local culture - are all important facets in the shaping of a vernacular region. The Nominee is one of the few scholars in the Atlantic region to study and analyze the vernacular architecture in the Maritimes and Newfoundland. (R. MacKinnon 2002; Pocius 1982, 2000; Ennals and Holdsworth).

The term "vernacular" has been used interchangeably in much architecture scholarship with the terms "folk," "common," or "native" architecture. One scholar, Kingston Heath, uses the analogy of a "filter" to define the vernacular in architecture. He argues that a fixed locale or region, with its unique character, cultural mix, values, materials, climate and topography can "filter" the conventional ideas about architecture whether they be folk, popular or high style (Heath 1984: 5). Folklorist Henry Glassie says the study of vernacular architecture, "favors completeness, recognizes diversity, and seeks ways to use buildings as evidence in order to tell better versions of the human story." (Glassie 2000: 21).

Architecture is only one aspect of the material culture of a cultural region. The architecture and all other artifacts that people make and use can be diagnostic; these can reveal much about economy, tradition and changes in people's attitudes and values over time. The Nominee will continue to research aspects of the region's vernacular architecture and material culture. For example, the island's barns, as with many regions of North America, are currently threatened. New farming hay storage techniques, and the loss of the small, family farm, make the need for large, wooden hay storage barns unnecessary. These buildings are disappearing from the Canadian and American landscape at an alarming rate. The construction techniques employed - the use of hand-hewed, heavy timber framing with mortice and tenon joints - is extremely old. It is necessary to record examples of this tradition and 
its accompanying terminology before it is no longer extant in the North American landscape. Cape Breton Island can serve as an international lab for the study of threatened buildings such as barns. Recording, measuring and interviewing with tradition bearers is needed to provide a thorough analysis of this disappearing tradition.

Another material culture project to be undertaken by the Research Chair is the biography of influential woman, Mary Arnold, one of the first female architects in North America. Although not a formally sanctioned member of the architecture profession, she was designing buildings throughout North America throughout the twentieth century. She helped design three Cape Breton Island neighborhoods in the 1930s, and designed buildings and neighborhoods in Newfoundland, Maine, New York, and Pennsylvania before her death in 1976. She was a feminist, writer, architect, and community economic developer who dared to design affordable housing for working people throughout North America. Perhaps her most influential building was a twelve story apartment complex in New York City, designed in the 1920s for working women. The building boasted "kitchenless" apartments and a cooperative cafeteria on the ground floor. In Philadelphia she designed small, affordable bungalows for a mixed black and white neighborhood that was complete with a man-made pond and a building for community meetings. The neighborhoods in Cape Breton Island were cooperative housing groups following the philosophy of Moses Coady and Jimmy Tompkins (Lotz and Welton 1997). This book project will produce a biography of this influential woman through a close analysis of what she left behind in the form of apartment buildings, neighborhoods, cooperative housing and credit unions throughout North America.

\section{Establish the Centre for Cape Breton Studies}

One way for the Canada Research Chair to develop and strengthen its research capacity in the social sciences and humanities is to encourage and support research on or about Cape Breton Island. Islands around the world have distinctive identities and are interested in exploring, researching and understanding their identities, histories and economies, that are deeply rooted in cultural heritage. The establishment of a Centre for Cape Breton Studies at Cape Breton University focusing precisely on cultural traditions will be a major step forward for Canada to develop a worldwide specialty in this area. A regional centre such as this is important in the era of globalization. A deeper understanding of 
tradition, folklore and values should result from this centre and its work. This, in turn, can influence public policy issues at the provincial and federal levels and can be generalized for global application in communities with similar issues.

The establishment of relationships with other centres for the study of regional culture throughout the world would be a priority, especially linkages with Centres for Canadian Studies. The Centre for Cape Breton Studies will be similar to the Centre for Canadian Studies at the University of Leeds, which has a focus on research about Canada. The Leeds Centre is recognized by the Canadian High Commission as a Regional Canadian Studies Centre. Similar recognition will be sought by the Cape Breton Centre from various Associations of Canadian Studies throughout the world.

Activities of the Cape Breton Centre will include a lecture/ workshop series, creation of partnerships with other Centres for Canadian, Aboriginal, Celtic, Irish, or Island Studies, create opportunities for visiting scholars, emerging scholars, and postdoctoral fellows to conduct research at CBU; develop further Visiting Endowed Chairs in a variety of allied areas such as Mi'kmaq Studies, Acadian Studies, Irish Studies, Celtic Studies, etc.; develop newsletters, sponsor colloquia, conferences and publications in the field of intangible culture and heritage; initiate graduate level studies in folklore and cultural heritage; and develop regional, national and international networks and research alliances with other research centres.

The proposed Centre for Cape Breton Studies will produce an interdisciplinary journal devoted to the distinctive society and culture of Cape Breton Island. It will publish under the auspices of the Centre for Cape Breton Studies, CBU, with the direction of an international Editorial Board. Essays submitted will be peer-reviewed. The journal will include academic articles in a variety of disciplines and multidisciplinary essays as well as more popular and practical articles and notes including book, film and new media reviews. The intended audience for this journal will not only be scholars, but also the welleducated general public. In essence, the centre will act as a multidisciplinary forum for faculty and students, as well as visiting researchers from other institutions, including government agencies. The centre will sponsor visiting lecturers, academic conferences, and public workshops on topics of relevance to intangible cultural heritage. 


\section{References}

Balcom, B. A. 1984. The Cod Fishery of Isle Royale 1713-58. Ottawa: Parks Canada, Minister of Environment.

Bowen, Lynne. 1987. Boss Whistle. Lantzville: Dolichan Books, 1982. .1987. Three Dollar Dreams. Lantzville BC: Oolichan Books.

Buchan, David. 1981. "MUN's Folklore Department: the Newfoundland Dimension." Bulletin of the Folklore Studies Association of Canada 5 $(3-4):$ 25-29.

Campbell, Douglas F. 1997. Banking on Coal: Perspectives on a Cape Breton Community within an International Context. Sydney: UCCB Press.

Candow, James E. ed. 2001. Industry and Society in Nova Scotia: An Illustrated History. Halifax: Fernwood.

Carpenter, Carole Henderson. 1979. Many Voices: A Study of Folklore Activities in Canada and their Role in Canadian Culture. CCFCS paper 26. Ottawa: National Museum of Man.

Celtic Colours web site, http://www.celtic-colours.com/ Generalinfo.html, visited on November 15, 2007.

Colls, Robert. 1977. The Collier's Rant. London: Croom Helm.

Davey, William and Richard MacKinnon. 1996. "The Use of Nicknames in Cape Breton." In Carol Corbin and Judith A. Rolls eds., The Centre of the World at the Edge of a Continent: Cultural Studies of Cape Breton: 197-220. Sydney, NS: University College of Cape Breton Press.

Doherty, Elizabeth A. 1996. The Paradox of the Periphery: Evolution of the Cape Breton Fiddle Tradition, 1928-1995. Doctoral dissertation, University of Limerick.

Dorson, Richard ed. 1982. Folklore and Folklife: An Introduction. Chicago: University of Chicago Press.

Dunlay, Kate. Traditional Celtic Violin Music of Cape Breton. Toronto: Dungreen Music, 1996.

Earle, Michael. 2001. "The Building of Steel Union Local 1064, Sydney, 1935-1937." In James E. Candow ed., Industry and Society in Nova Scotia: An Illustrated History: 39-56. Halifax: Fernwood.

Feintuch, Burt. 2002. The Heart of Cape Breton: Fiddle Music Recorded live along the Ceilidh Trail of Cape Breton (CD). Washington: Smithsonian Folkways Records.

Fowke, Edith. 1969. "Labour and Industrial Protest Songs in Canada." Journal of American Folklore 82(323): 34-50. 
Frank, David. 1999. J.B. McLachlan: A Biography. Toronto: James Lorimer.

- 1985. "Tradition and Culture in the Cape Breton Mining Community in the Early Twentieth Century." In Ken Donovan ed., Cape Breton at 200: Historical Essays in Honor of the Island's Bicentennial 1785-1985: 203-218. Sydney: UCCB Press.

and Donald MacGillivray. 1987. George McEachern, an Autobiography: The Story of a Cape Breton Labor Radical. Sydney: University College of Cape Breton Press.

Glassie, Henry. 2000. Vernacular Architecture. Bloomington: Indiana University Press.

Green, Archie. 1972. Only a Miner: Studies in Recorded Coal Mining Songs. Urbana: University of Illinois Press.

Halpert, Herbert and Neil V. Rosenberg. 1974. "Folklore Work at Memorial University." Canadian Forum 53 (638): 31-32.

Heath, Kingston and William Balcom. 1984. The Cod Fishery of Isle Royale 1713-58. Ottawa: Parks Canada, Minister of Environment. Heron, Craig. 1988. Working in Steel: The Early Years in Canada, 18831935. Toronto: McClelland and Stewart.

Hornsby, Stephen. 1992. Nineteenth Century Cape Breton: A Historical Geography. Montreal and Kingston: McGill-Queen's University Press. Hufford, Mary ed. 1994. Conserving Culture: A New Discourse on Heritage. Urbana and Chicago: University of Illinois Press. 1986. One Space, Many Places: Folklife and Land Use in New Jersey's Pinelands National Reserve. Washington: American Folklife Center.

Innis, Harold Adams. 1978. The Cod Fisheries: The History of an International Economy. Toronto: University of Toronto Press. Jackson, Bruce. 1987. Fieldwork. Urbana: University of Illinois Press. Knapp, Bernard A. et al. 1998. Social Approaches to an Industrial Past:

The Archaeology and Anthropology of Mining. London: Routledge. Korson, George. 1979. Black Rock: Mining Folklore of the Pennsylvania Dutch. Pennsylvania: Ayer Publishing Company. . 1965. Coal Dust on the Fiddle. Hatboro: Folklore Associates. 1965. Minstrels of the Mine Patch. Hatboro: Folklore Associates.

Loomis, Ormond. 1983. Cultural Conservation: The Protection of Cultural Heritage in the United States. Washington D.C.: American Folklife Centre, Library of Congress.

Lotz, Jim and Michael Welton. 1997. Father Jimmy: Life and Times of Jimmy Tompkins. Sydney: Breton Books. 
MacEwan, Paul. 1976. Miners and Steelworkers: Labour in Cape Breton, Toronto: Hakkert.

MacGillivray, Allister. 1988. A Cape Breton Ceilidh. Sydney: Sea Cape Music.

- 1981. The Cape Breton Fiddler. Sydney: City Printers.

MacGillivray, Don. 1980. "Military Aid to the Civil Power: The Cape Breton Experience." In Don MacGillivray and Brian Tennyson eds., Cape Breton Historical Essays: 95-109. Sydney, NS: University College of Cape Breton Press.

MacInnes, Sheldon. 1997. A Journey in Celtic Music: Cape Breton Style. Sydney: UCCB Press.

MacKinnon, Ian. 1989. "Fiddling to Fortune: The Role of Commercial Recordings Made by Cape Breton Fiddlers in the Fiddle Tradition of Cape Breton Island." Masters Thesis, Department of Folklore, Memorial University of Newfoundland.

MacKinnon, Richard. 2000. "Humorous Nicknames in Industrial Cape Breton." In Pauleena MacDougall and David Taylor eds., Northeast Folkore: Essays in Honor of Edward D. Ives: 353-362. Orono, Maine: University of Maine Press and the Maine Folklife Center.

McKay, Ian. 1988. "The Crisis of Dependent Development: Class Conflict in the Nova Scotia Coalfields, 1872-1876." In Gregory S. Kealey ed., Class, Gender and Region: Essays in Canadian Historical Sociology: 9-48. St. John's, Newfoundland: Memorial University of Newfoundland.

Mellin, Robert. 2003. Tilting: House Launching, Slide Hauling, Potato Trenching, and Other Tales from a Newfoundland Fishing Village. New York: Princeton Architectural Press.

Muise, Delphin and Robert G. McIntosh. 1996. Coal Mining in Canada:

A Historical and Comparative Overview. Ottawa: National Museum of Science and Technology.

Newsome, Eric. The Coal Coast: The History of Coal Mining in British Columbia, 1835-1900. Victoria (BC): Orca Book Publishers, 1989. Pocius, Gerald L. 2000. "Academic Folklore Research in Canada Trends and Prospects (Part1)." Ethnologies 22(2): 255-280.

_. 1982. "Architecture on Newfoundland's Southern Shore: Diversity and the Emergence of New World Forms." In Camille Wells ed., Perspectives in Vernacular Architecture: 217-232. Annapolis: Vernacular Architecture Forum. 
2000. A Place to Belong: Community Order and Everyday Space in Calvert, Newfoundland. Montreal: McGill-Queen's University Press.

Preston, Dennis Richard. 1975. Bituminous Coal Mining Vocabulary of the Eastern United States. Alabama: The University of Alabama Press for the American Dialect Society.

Ryan, Judith Hoegg. 1992. Coal in Our Blood: 200 Years of Coal Mining in Nova Scotia's Pictou County. Halifax: Formac.

UNESCO. 2003. International Convention for the Safeguarding of the Intangible Cultural Heritage, 17 October. 